\title{
Partial Budgeting Analysis of an Intervention of 'Land Shaping Technology' at South 24 Parganas, West Bengal, India
}

\author{
Ajit Kumar Roy* \\ Ex. Principal Scientist \& Head Social Science Section, Kausalyaganga, Bhubaneswar, India
}

*Corresponding author: Ajit Kumar Roy, Ex. Principal Scientist \& Head Social Science Section, Kausalyaganga, Bhubaneswar, India

\begin{abstract}
Reported Impact Assessment of an intervention 'Land Shaping Technology' implemented at farmer's field under NAIP project at different villages of south 24-Pargans district of West Bengal aiming for rainwater harvesting for irrigating crops. Farm data was collected from the randomly selected farmers of both Interevent and control groups. Partial budgeting analysis was done to assess the comparative performances with respect to sources of income and livelihoods, diversification of input cost, labour cost, employment generation, production etc. The impact of Land Shaping technology can be assessed from the fact that the landscape and cropping pattern has been changed from single crop to multi crop round the year resulting in enhanced productivity, employment generation, income and related activities arresting migration of people to cities in search of jobs for livelihood in intervened farmer's plots compared to those in control plots. Livelihood opportunities have increased considerably in the area without affecting the environment. Beneficiaries and family members are observed fully engaged in farming, marketing and associated activities. Many people have been affected directly and indirectly in agriculture related activities like farming, input supply, trading, marketing and transport operations as a result of intervention of the proven technology of ICAR-CSSRI adopted by NAIP for field extension. The Land Shaping Technology having potential of manifold increase productivity in the low-lying saline belt of Sundarbans which otherwise depends on seasonal rain, may be continued to a wider section of non-beneficiaries for long term social, economic, benefit and social equity resulting in a balanced society framework.
\end{abstract}

Keywords: Impact Assessment; Partial Budgeting; Input; Output; Cost; Livelihood; Employment Generation; Income

\section{Introduction}

India is one of the fastest growing economies in the world, ranked among the top ten highest GDP countries, and is the world's second most populous country. During the past two decades, India's GDP grew at an average of 7 percent annually. In spite of impressive economic growth and poverty alleviation, India is now at a critical juncture in its paths towards becoming an economic powerhouse and is facing important development challenges and structural constraints to a more inclusive growth and a more sustainable development. India remains home to 263 million poor people most of which reside in rural areas. The economic growth has not generated jobs fast enough to absorb labour out of agriculture and low productivity rural jobs. To address these challenges, the Government of India (GOI) has in recent years focused on accelerating economic growth and poverty reduction, creating jobs, improving environmental management and achieving an annual growth in the agriculture and allied rural sectors of 4 percent in its Union Budget, 2017-18, GOI articulated its resolve to double farmers' income in 5 years. It is widely accepted that Agriculture sector's growth is essential in achieving India's development goals. The sector currently accounts for 14 percent of national GDP and is a source of livelihood for more than half of the population. More than two thirds of the country's poor live in rural areas, and their chance of getting out of poverty directly depends on the performance of agriculture and allied rural sectors. The agriculture sector also has a major potential for creating rural employment and alleviation of poverty. Against this backdrop, Government of India initiated through a Mega project entitled 'National Agricultural Innovation Project (NAIP)', funded by World Bank was in operation throughout 
the whole country and implemented through State Agricultural Universities, ICAR Institutes and NGO organization that operated in farmer's field with proven technologies from various fields of Agriculture, Animal Science, Forestry, Fisheries etc.

Under the subproject 'Strategies for Sustainable Management of Degraded Coastal land and Water for Enhancing Livelihood Security of the Farming Communities' an intervention named 'Land Shaping' for improving rainwater harvesting and drainage for enhancing productivity at low lying degraded land including Tsunami affected land at the District South 24 Parganas in the state of West Bengal' was extended to farmer's field termed as Intervention (treated). The main objectives of Intervention were

i) Sustainable enhancement of the productivity of degraded land and water resources of the coastal region through integrated approaches.

ii) Enhancement of livelihood security and employment generation for the poor farming communities of the coastal region.

iii) Empowerment through capacity building and skill development of stakeholders including men and women farmers.

\section{Type of Assistances Provided to Farmers}

Farmers plots/farm was constructed by NAIP; Formation of sustainable fund; Information regarding better input availability \& supply like Paddy (Aman, Mona, Gitanjali, Chaitali), Paddy seed \& Vegetable seed (Tejeswari, Avinash3, VNR28, 1458, 6214 etc.). After completion of implementation of the project, NAIP intended to assess the impact of the sub-projects based on the basic parameters of effectiveness, efficiency, results/impact and sustainability. More precisely, NAIP wants to undertake Outcome Focused Impact Evaluation of sub-projects with the aim of Identification and quantification of the field level impacts of the project interventions in terms productivity, profitability, sustainability, employment, equity, gender, input saving, cropping intensity, etc.

One of the Technology Intervention named 'Land Shaping Technology' was taken up as an intervention for improving rainwater harvesting and drainage for enhancing productivity in the Sundarbans region was assigned to me for carrying out Impact Assessment Study. Earlier reports on impact assessment study on various interventions are reported worldwide covering methodology as well as field implementations from FAO, UNDP, UN, World Bank, ADB, NAIP and different researchers on various crops technologies, intervention and scenario [1-31]. As it is known that Partial budget analysis is a simple but effective technique for assessing the profitability of new technology for an existing enterprise. It also provides the foundation for comparing the relative profitability of alternative treatments, evaluating their riskiness, and testing how robust profits are in the event of changing product or input prices. The method developed by International Wheat and Maize Improvement Centre (CIMMYT), is extensively used for estimating the financial impact of implementing a new technology, in dairy research and plant protection research and on various crops. Reports on Partial Budgeting, economic analysis, Partial Budget to Analyse Farm Change, to estimate the cost and benefit of adaptation of a new technology, Partial budgeting technique, assessment of New technology that can be evaluated in terms of its impact on the productivity, profitability, acceptability and sustainability of farming systems are available [32-41].The present study is attempted to evaluate the impact assessment of intervention of 'Land Shaping Technology, developed by ICAR-CSSRI and extended under NAIP project on farmer's field utilizing the Partial budgeting technique in terms of productivity, profitability, acceptability and sustainability of farming systems.

\section{Methodology for the Present Impact Assessment Household Survey}

i) Experimental Design: In the present impact assessment study Ex Post design was adopted with provision for comparison between Intervened and control group of households. Both qualitative and quantitative data through random sampling and purposive selection method is taken for collection of Primary data for both treated and control groups of household farmers respectively.

ii) Survey Instrument /Assessment Tools for Household Survey: After thorough discussion the survey instrument designed by NAIP was taken up for field data collection. The questionnaire was designed mainly for financial impact assessment was administered for primary data collection from the field.

iii) Sample Size Selection: As per PIU, NAIP guideline that at least 30 random samples of beneficiary farmers and 20 samples of control group farmers to be covered for primary $\mathrm{HH}$ data collection for the intervention, from the frame of beneficiary farmer's household. In case of non-beneficiary farmers (control) purposive sample method is resorted to from the neighbouring areas where intervention was made.

iv) Sources of Data Collection: Primary and secondary sources: Household survey, Market visits, Field Observations, Key informants Interview and Transect walk besides Existing literature of best practice of IA survey/study, NAIP Project documents, Reports, etc.,

v) Overall Field Observation: Financial data in prescribed questionnaire aiming Partial Budgeting of Interventions collected to capture change in profit particularly Household assets, sources of income and livelihoods, diversification of input cost, labour cost, employment generation, production etc. were 
emphasized for field data collection. Besides few qualitative parameters like income, profit, adoption, sustainability, etc., are also covered. Key informant Interview/farmers' meet/transect walk were also organized for each intervention taken up at each site to take stock of the present scenario and validation.

vi) Partial budgeting technique was employed to estimate the cost and benefit of adaptation of 'Land Shaping Technology'.

vii) Areas of Operation/Geographical Location: Disadvantaged coastal district of South 24 Parganas, West Bengal: Blocks: Canning I, Basanti, Mathurapur II, Patharpratima, Kultali, Namkhana, Kakdwip (6 clusters -18 villages) and Consortium Partners: CSSRI, Canning Town; RKM-KVK, Nimpith; KRC, ICARCIBA, Kakdwip, South 24-Parganas. viii) Identification of Interventions and Sampling Methodology and Framework: Identified interventions through discussion with PIU, NAIP and CPI's, CCPI's of consortium partners and followed by field visit to arrive at a final decision on selection of appropriate interventions to cover under impact assessment survey located at south 24 Parganas district of West Bengal. From the frame of beneficiary farmer's household, sample is selected at random to avoid bias. In case of non-beneficiary farmers (control)purposive sampling method is resorted to because in the given time frame construction of sampling frame of control farmers followed by random selection was next to impossible. NAIP intervention of 'Land Shaping' is shown in Figure 1.
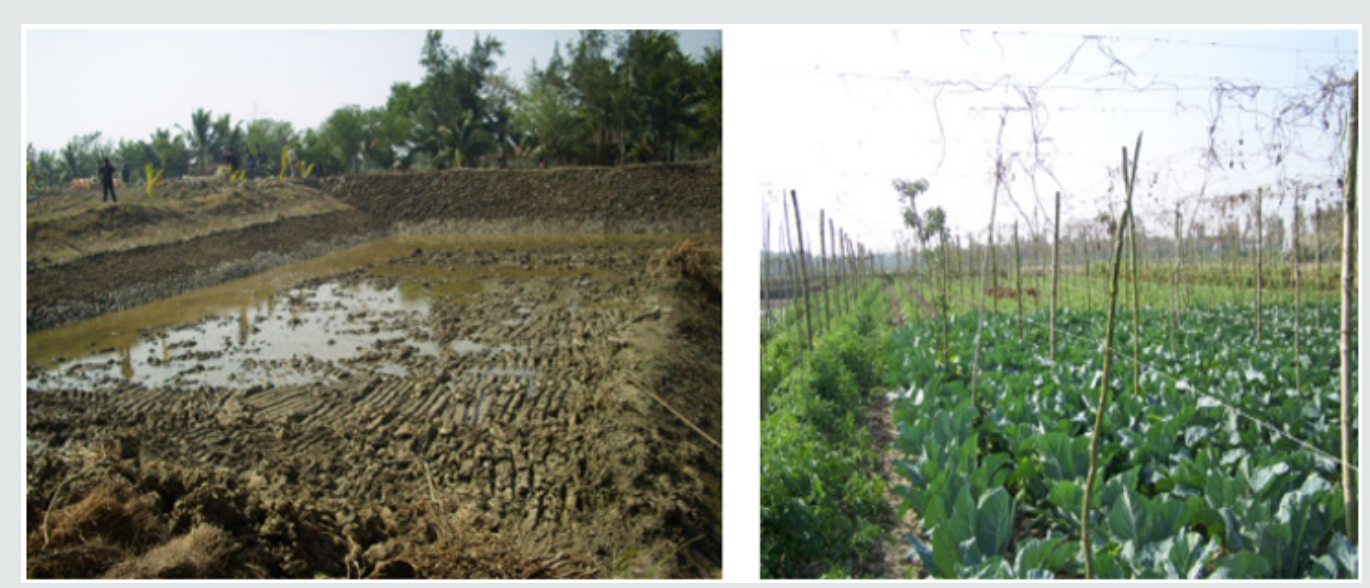

Figure 1: Intervention Land Shaping Technology Digging pond of Farmers by NAIP, CSSRI, Canning, \&KVK, R.K.Missin, Nimpith, Sundarbans, West Bengal.

\section{Results and Discussions}

\section{Financial Analysis and Partial Budgeting}

Partial budgeting also known as marginal analysis is a management tool that can compare the costs and returns that are affected by a potential change in an intervention. It is especially useful in evaluating budgets that involve small, specific, and limited changes within an intervention by helping to determine the profitability of that change. The partial budget can be divided into three main sections: (I) costs, (II) benefits, and (III) analysis. The analysis section includes net change in profits and a break-even analysis also known as benefit/cost ratio. The possible changes that can occur in an intervention fall into four categories. These categories are added returns, reduced returns, added costs, and reduced costs. The analysis section of the partial budget contains both net change in profits and benefit/cost ratio analysis. In this section as part of partial budgeting an attempt has been made to present and discuss comparative figures of the socio-economic status of farm households (adopted-30 \& control 20) in terms of basic production assets, Area under various activities, Employment Generation, Cost of Cultivation (in Rs. / Acre), Income (Rs. / Acre) and cost benefit ratio. Financial impact analysis based on primary data collected from fields of intervention.

\section{Cropping Pattern}

It reveals from the survey data of households that there is a distinct difference between the cropping pattern of adopted treated households for the intervention land shaping aiming for improving rainwater harvesting and drainage for enhancing productivity at low lying degraded landat the District South 24 Parganas in the state of West Bengal compared to those in the Control farmers selected from the neighbouring areas. As a result of intervention in the form of digging ponds for rainwater harvesting, availability of water for irrigation for cropping on the pond dyke for vegetable cultivation was available. Depending on the size of the pond irrigation was available for the neighbouring plots also almost round the year whereas in the control plots famers used to cultivate one seasonal crop like conventional low yielding paddy. On the treated plots good quantity of vegetables like tomato, bitter gourd, cucumber, brinjal etc. were grown. This practice resulted in high production from unit area accruing higher output. Therefore, it is attempted to depict the input, output, components of cost of cultivation, 
components of input cost, output in the form of table and graphs for easy understanding of the differences between treated and control farmers.

\section{Yield Comparison between Treated and Control Plots}

Yield of crop, vegetable and Fish are observed 1.66, 1.92 and 2.68 higher respectively in the intervened plots compared to those produced in control (Figure 2).

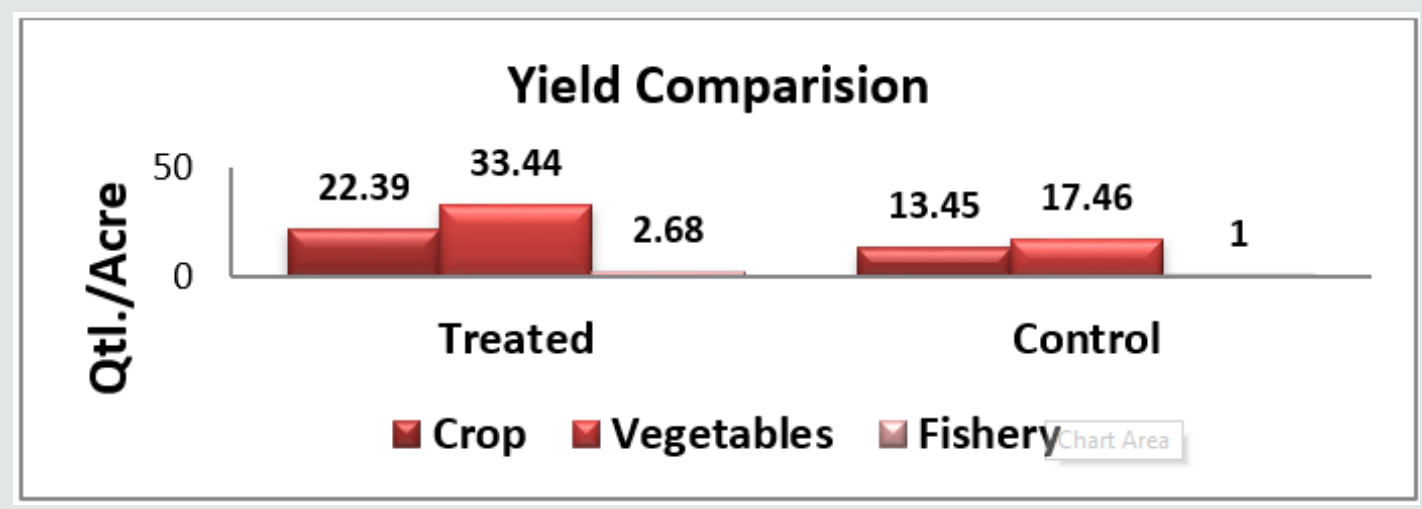

Figure 2: Yield Comparison; Intervention: Land shaping for improvement of rainwater harvesting, District South 24 Parganas, West Bengal.

\section{Employment Generation}

It was one of the most important objectives to assess the impact of the technology intervention on employment generation compared to the control group and as such presented in Figure 3. Employment generation was also higher for male, female and total in the intervened plots to the extent of $1.7,2.36$ and 1.95 times respectively compared to those generated in the control group.

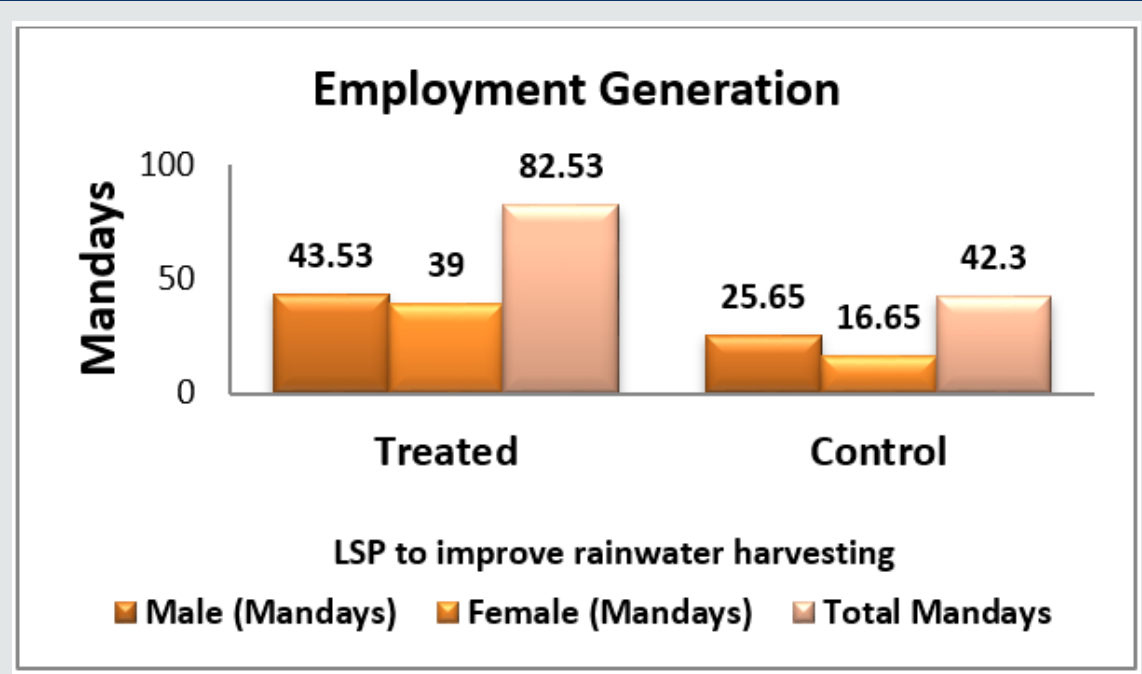

Figure 3: Comparison of Employment Generation between Treated \& Control Plots.

\section{Cost of Cultivation}

An account of cost of cultivation being a very important factor is being compiled and presented for both intervened and control groups and displayed in table for comprehension of changes that has occurred as a result of adoption technology compared to the control groups (Table1).

Table 1: Cost of Cultivation (Rs. / Acre) of the intervention (Treated VS Control).

\begin{tabular}{|c|c|c|}
\hline Field & Intervened/Treated & Control \\
\hline Average Labour cost (in Rs.) & 20759.74 & 9794.20 \\
\hline Average Farm power cost (in Rs.) & 5945.67 & 3031.21 \\
\hline Material Inputs cost (in Rs.) & 13759.39 & 5235.85 \\
\hline Other associated cost (in Rs.) & 38.94 & 38.28 \\
\hline Total capital/long term investment per year (in Rs.) & 6191.49 & 2578.02 \\
\hline
\end{tabular}




\begin{tabular}{|c|c|c|c|}
\hline Other cost if any (in Rs.) & 0 & 0 & 0 \\
\hline $\begin{array}{l}\text { Total cost of cultivation (in Rs. / acre) without support from } \\
\text { NAIP }\end{array}$ & 46695.24 & 21358.85 & 25336.39 \\
\hline Support provided by the project (in Rs.) & & N.A. & \\
\hline $\begin{array}{l}\text { Average support provided in Capital cost/long term } \\
\text { investment (in Rs.) }\end{array}$ & 6191.44 & N.A. & \\
\hline Total support provided from project (in Rs.) & 6191.44 & N.A. & \\
\hline Actual cost of cultivation borne by farmer (in Rs/Acre) & 40503.80 & 21358.85 & 19144.95 \\
\hline
\end{tabular}

\section{Interpretation of Cost of Cultivation}

Cost of cultivation was observed 1.9 times higher in treated plots compared to that incurred in the control plots (Table1). Component wise break up of cost of cultivation within treated plots it is seen that on an average labour cost constituted $45 \%$ followed by material input cost(29\%),capital investment(13\%) and farm power $(13 \%)$ whereas cost of cultivation for control plots were on an average are found labour(47\%),material input(25\%),farm power $\operatorname{cost}(15 \%)$,and capital $\operatorname{cost}(13 \%)($ Figure 4). Further partitioning of input cost for treated group exhibits that the highest cost of cultivation was borne toward Fertiliser(46\%) followed by fish fingerling(17\%),seed(12\%) and the rest $12 \%$ jointly by seed treatment, feed cost \& pond maintenance but in case of Control group the highest cost incurred was on account of Fertilise(55\%) followed by seed(18\%)pesticide(17\% and seed treatment(10\%) (Figure 5). It is interesting to note that in the intervened one NAIP dug pond for rainwater harvesting that facilitated not only irrigation for crops and vegetables but also fish culture also resulting in higher return from unit area where as in the control plots farmers cultivated single crop of paddy and some seasonal vegetables only as can be evidenced from expenditure pattern and Input use.
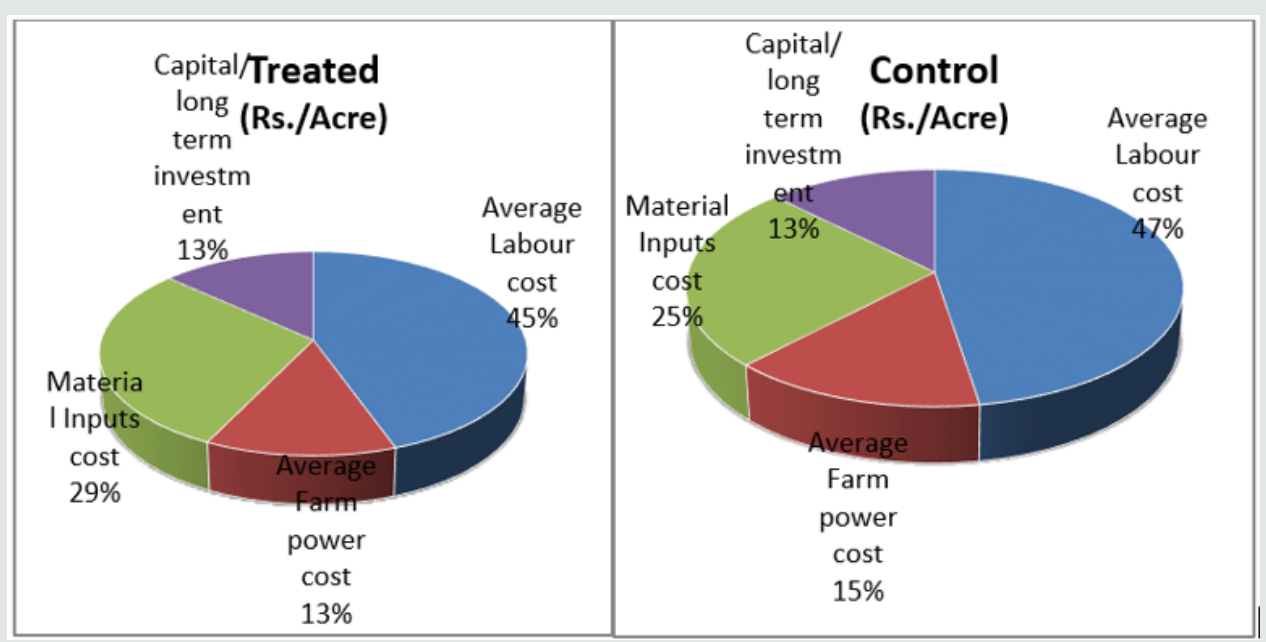

Figure 4: Pie Chart showing Comparative Cost of Cultivation; Intervention: Land shaping for improvement of rainwater harvesting, District South 24 Parganas, West Bengal.

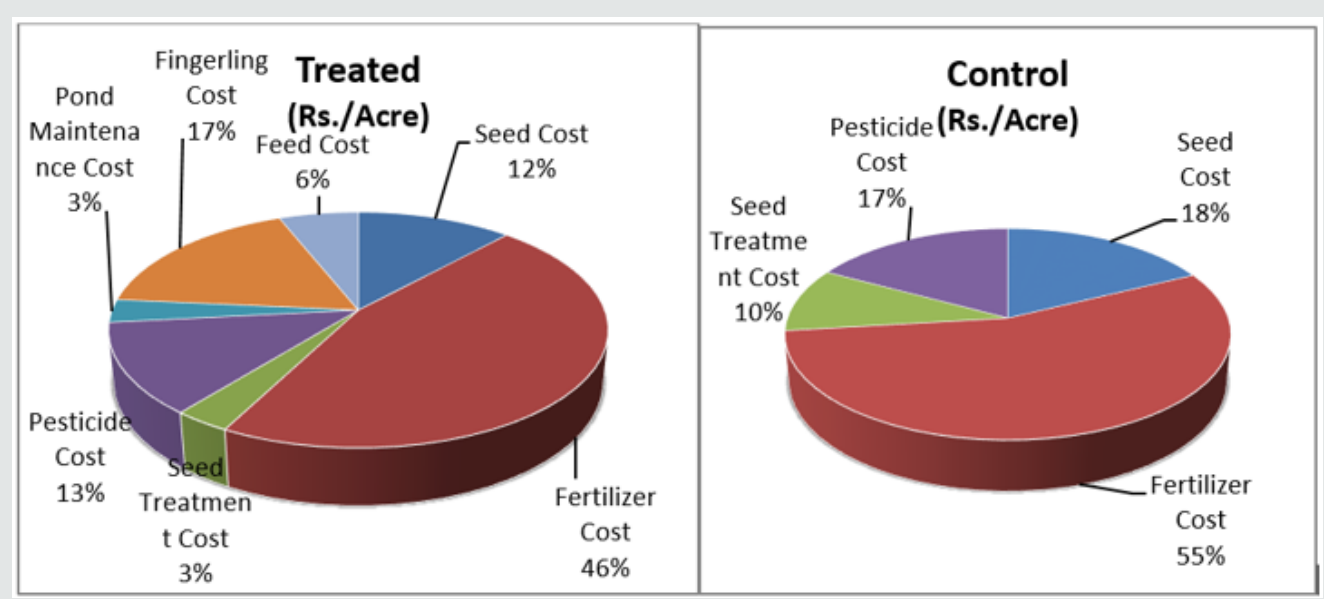

Figure 5: Pie Chart showing Comparative Cost of Material Input; Intervention: Land shaping for improvement of rainwater harvesting, District South 24 Parganas, West Bengal. 


\section{Income}

A complete picture of Income (in Rs. / Acre) (Intervention: Land Shaping technology): Treated VS Control is presented in Table 2.

\section{Interpretation of Accrued Income}

The ultimate interest is income for any enterprise. Therefore, details of gross income, net income profit and cost benefit ratio is presented side by side for comparison of treated and control groups of farmers. Details of gross income, net income, profit and cost benefit ratio is presented side by side for comparison of treated and control groups of farmers (Table 2). It is clear from above table that in case of Treated group average income was Rs.31, 262/ acre as against a negative income of Rs -8936/acre from Control group. The same thing reflected in cost benefit ratio (Treated:1.37\&
Control -0.42). It is well known that in theory, any project with a $\mathrm{B} / \mathrm{C}$ ratio exceeding 1 is worthwhile, most public agencies have recognized that there is some uncertainty associated with both the benefit and the cost estimates. Accordingly, it is not uncommon for agencies to desire a threshold of $\mathrm{B} / \mathrm{C}$ exceeding 1.5 for large new projects, and 1.3 for incremental projects in which uncertainty is less. The present case B/C ratio is at threshold level. Moreover; Added returns and reduced costs fall into the benefits section of the partial budget and are the positive effects of a proposed change in the business as can be evidenced from the present analysis. Here the net change between positive and negative economic effects is an estimate of the net effect of making the proposed change in the total farm budget. A positive net change indicates a potential increase in income and a negative net change indicates a potential reduction in income due to the proposed change (Figure 6).

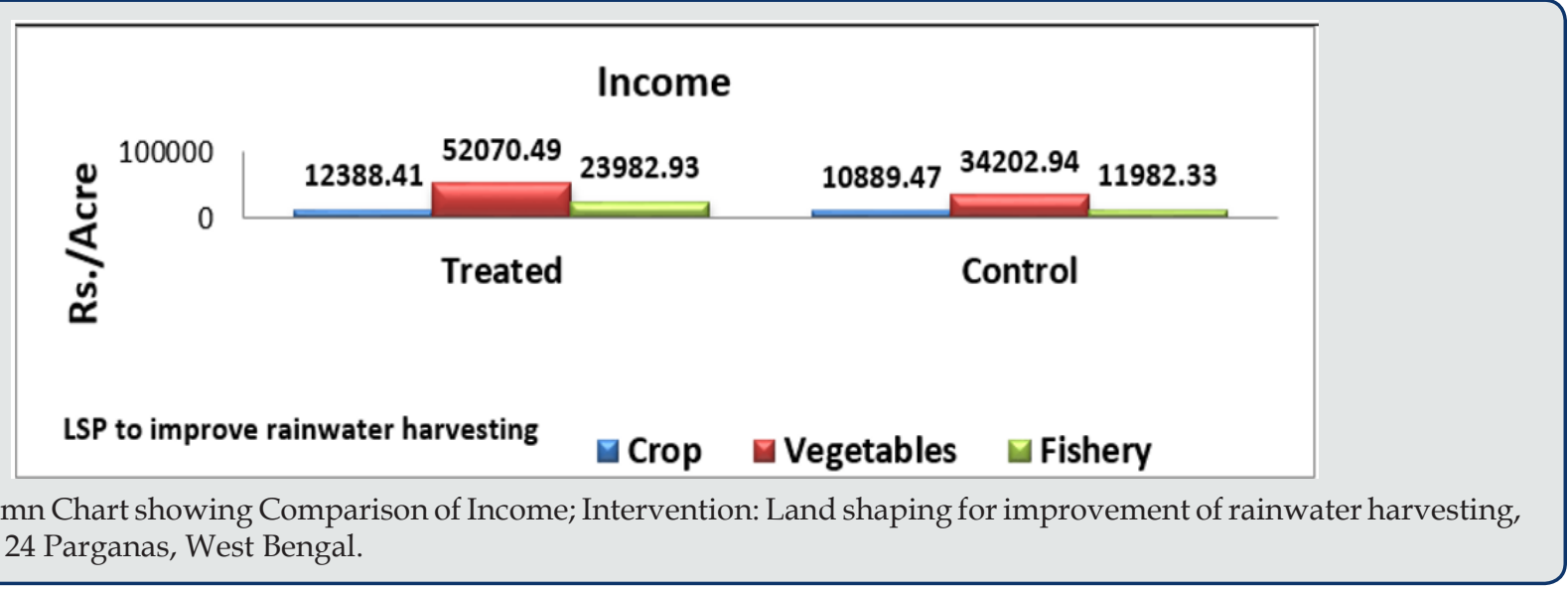

Table 2: Income (Rs. / Acre) at the intervention of Land shaping :( Treated VS Control).

\begin{tabular}{|c|c|c|c|}
\hline Field & Treated & Control & Comparison \\
\hline Income from crop (in Rs. /Acre) & 13916.18 & 0 & 13916.18 \\
\hline Income from vegetable (in Rs. /Acre) & 57339.17 & 0 & 57339.17 \\
\hline Income from straw (in Rs. / Acre) & 763.86 & 440.01 & 323.85 \\
\hline Income from Fishery (in Rs. /Acre) & 23982.93 & 11982.33 & 12000.60 \\
\hline Income from poultry (in Rs. /Acre) & 8537.25 & 0 & 8537.25 \\
\hline Income from Livestock (in Rs. /Acre) & 0 & 0 & 0 \\
\hline Gross Income generated (in Rs. /acre) & 104539.38 & 12422.34 & 92117.04 \\
\hline $\begin{array}{l}\text { Subtract total cost of cultivation without support from NAIP } \\
\qquad \text { (in Rs. /Acre) }\end{array}$ & 46695.23 & 21358.85 & 25336.39 \\
\hline Net Income (in Rs. /acre) without support from NAIP & 57844.15 & -8936.51 & 66780.65 \\
\hline Add support provided from NAIP (in Rs. /Acre) & 6191.44 & N.A. & \\
\hline Net Income (in Rs. /acre) with support from NAIP & 64035.59 & -8936.51 & 72972.09 \\
\hline Benefit cost ratio* & 1.37 & -0.42 & \\
\hline Profit from competing crop/Agro-enterprise (in Rs. /Acre) & 31262.13 & 2869.72 & \\
\hline
\end{tabular}

\section{Variability in Financial Parameters}

Descriptive statistics of various parameters are presented for Treated Group (Table 3) and control group (Table 4). The coefficient of variation of Total Cost of Cultivation, Total Income (Rs. /Acre) (Rs. /Acre) and Profit from competing agro-enterprise (Rs. /Acre) are observed to be $45.88,36.20$ and $79.27 \%$ respectively. and the same 
for the control group are estimated to be $47.88,23.79$ and $100 \%$ showed $100 \%$ coefficient of variation. These high variations respectively. Surprisingly profit from competing agro-enterprise indicate an alarming scenario of inconsistency in parametric values.

Table 3: Descriptive Statistics of some financial parameters of the Intervention: Land shaping (Adopted Farmers) to improve rainwater harvesting - South 24 Parganas, West Bengal (Treated).

\begin{tabular}{|c|c|c|c|c|c|c|c|}
\hline \multicolumn{2}{|c|}{$\begin{array}{l}\text { Descriptive } \\
\text { Statistics }\end{array}$} & $\begin{array}{l}\text { Total area } \\
\text { Under Control } \\
\text { of Farmer } \\
\text { (Acre) }\end{array}$ & $\begin{array}{l}\text { Area under NAIP } \\
\text { Intervention } \\
\text { (Acre) }\end{array}$ & $\begin{array}{l}\text { Capital Support } \\
\text { Provided by NAIP } \\
\text { (Rs. /Acre) }\end{array}$ & $\begin{array}{l}\text { Total Cost of } \\
\text { Cultivation (Rs. } \\
\text { /Acre) }\end{array}$ & $\begin{array}{l}\text { Total Income } \\
\text { (Rs. /Acre) }\end{array}$ & $\begin{array}{l}\text { Profit from Competing } \\
\text { agro-Enterprise (Rs. / } \\
\text { Acre) }\end{array}$ \\
\hline \multicolumn{2}{|c|}{ Average } & 1.7 & .89 & 6191.44 & 46695.24 & 97742.94 & 31262.13 \\
\hline \multirow{2}{*}{ 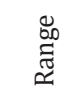 } & Max. & 3.72 & 2.4 & 7092.20 & 82375.47 & 71095.36 & 68671.39 \\
\hline & Min. & .34 & .15 & 2955.08 & 43943.62 & 63970.08 & 1714.40 \\
\hline \multicolumn{2}{|c|}{ Standard Deviation } & 1.13 & .82 & 3375.67 & 21423.45 & 35207.48 & 24782.85 \\
\hline \multicolumn{2}{|c|}{$\begin{array}{c}\text { C. V. (St Dev/ Avg x } \\
100)\end{array}$} & $66.47 \%$ & $92.13 \%$ & $54.52 \%$ & $45.88 \%$ & $36.02 \%$ & $79.27 \%$ \\
\hline
\end{tabular}

Table 4: Descriptive Statistics of some financial parameters of (Control Farmers).

\begin{tabular}{|c|c|c|c|c|c|c|c|}
\hline \multicolumn{2}{|c|}{ Statistical Analysis } & $\begin{array}{c}\text { Total area } \\
\text { under control } \\
\text { of farmer } \\
\text { (Acre) }\end{array}$ & $\begin{array}{l}\text { Area under NAIP } \\
\text { Intervention } \\
\text { (Acre) }\end{array}$ & $\begin{array}{l}\text { Capital Support } \\
\text { Provided by NAIP } \\
\text { (Rs. /Acre) }\end{array}$ & $\begin{array}{c}\text { Total Cost of } \\
\text { Cultivation (Rs. } \\
\text { /Acre) }\end{array}$ & $\begin{array}{c}\text { Total Income } \\
\text { (Rs. /Acre) }\end{array}$ & $\begin{array}{c}\text { Profit from competing } \\
\text { agro-enterprise (Rs. / } \\
\text { Acre) }\end{array}$ \\
\hline \multicolumn{2}{|c|}{ Average } & 1.10 & N. A. & N. A. & 20677.56 & 57514.76 & 2869.72 \\
\hline \multirow{2}{*}{$\begin{array}{l}\mathscr{\infty} \\
\underset{\varpi}{\approx} \\
\approx\end{array}$} & Max. & 1.86 & N. A. & N. A. & 23318.57 & 38352.52 & 26855.62 \\
\hline & Min. & .29 & N. A. & N. A. & 1482.14 & 1417.18 & -12.99 \\
\hline \multicolumn{2}{|c|}{ Standard Deviation } & .76 & N. A. & N. A. & 9900.34 & 13680.48 & 2869.98 \\
\hline \multicolumn{2}{|c|}{$\begin{array}{c}\text { C. V. (St Dev/ Avg X } \\
100)\end{array}$} & $69.09 \%$ & N. A. & N. A. & $47.88 \%$ & $23.79 \%$ & $100 \%$ \\
\hline
\end{tabular}

\section{Conclusion}

i) Relevance: Intervention of Land Shaping Technology by NAIP is relevant as the activities and outputs of the programme consistent with the intended impacts and effects as envisaged in objective of the programme.

ii) Effectiveness: The Intervention is found to be effective also as this intervention attained its objectives of rainwater harvesting and utilisation saline and Tsunami affected land for productive use to create employment and livelihood opportunities of marginal farmers of Sundarbans region of West Bengal State.

iii) Efficiency: Farmers adopting Land shaping technology have got higher output compared to that achieved in control group. From B/C ratio it is apparent that the technology is costefficient. Therefore, in the present case of intervention is found efficient.

iv) Sustainability: Sustainability is concerned with measuring whether the benefits of an activity are likely to continue after donor funding has been withdrawn. Projects need to be environmentally as well as financially sustainable. To what extent did the benefits of a programme or project continue after donor funding ceased? Uniqueness of this capital-intensive intervention / technology is that once the land shaping in the form of pond is done it will remain so and can be used for at least 5-10 years for productive purposes without much maintenance. Interviewing cross section of adopted/ non-adopted/control farmers in the area, the IA consultant got a clear idea that the farmers are going to continue with the technology even after the funding is discontinued. It is also observed that a lot of non-beneficiaries are also interested to adopt the technology but unable to do so because of paucity of fund of the poor and marginal farmers. Even it is reported that the Govt. of West Bengal and Sundarbans Development Board are investing substantial amount of resources to extend this technology to the entire Sundarbans region.

v) Impact: Impact is known as the positive and negative changes produced by a development intervention, directly or indirectly, intended or unintended. This involves the main impacts and effects resulting from the activity on the local social, economic, environmental and other development indicators. The impact of Land Shaping technology can be assessed from the fact that the landscape and cropping pattern has been changed from single crop to multi crop round the year resulting in enhanced productivity, employment generation, income and related activities arresting migration of people to cities in search of jobs for livelihood. Livelihood opportunities have increased considerably in the area without affecting the environment. Beneficiaries and family members are fully engaged in farming, marketing and associated activities. Many people have been affected directly and indirectly in agriculture 
related activities like farming, input supply, trading, marketing, transport operations etc.

\section{Recommendations}

The Land Shaping Technology having potential of manifold increase productivity in the low-lying saline belt of Sundarbans which otherwise depends on seasonal rain, may be continued to a wider section of non-beneficiaries for long term social, economic, benefit and social equity resulting in a balanced society framework

\section{Acknowledgement}

The author is grateful to NAIP, ICAR, New Delhi for granting me the project to carry out the work of impact assessment as an independent National Consultant. The field work and data collection work could not have been done without the active support of Scientists and technical staffs of RKM KVK, Nimpith and ICAR-CIBA, Kakdwip to whom I am highly indebted.

\section{References}

1. www.worldbaenk.org/ieg/noni

2. Asian Development Bank (ADB) (2006) Impact Evaluation: Methodological and Operational Issues. Manila, Philippines.

3. ADB (2006) Impact Evaluation-Methodological and Operational Issues, Economics and Research Department, Asian Development Bank, Manila, Philippines.

4. United Nations (2011a) The Millennium Development Goals Report 2011. Sales No. E.11. I.10.Food Policy Research Institute (IFPRI) and the Mexican Progress Anti-Poverty and Human Resource Investment Conditional Cash Transfer Program. Impact Assessment Discussion Paper27. Washington, DC, USA.

5. European Evaluation Society (EES) (2007) The Importance of a Methodologically Diverse Approach to Impact Evaluation-Specifically with Respect to Development Aid and Development Interventions. EES Statement, Nijkerk, Netherlands.

6. (1986) National Household Survey Capability Programme: Sampling Frames and Sample Designs for Integrated Household Survey Programmes, Preliminary Version (DP/UN/INT-84-014/5E), New York, USA.

7. Science Council (2006c) 'Impact Assessment of Policy-Oriented Research in the CGIAR: A Scoping Study Report'. CGIAR Science Council. Science Council (2006d) 'Spill over Increases Returns to Sorghum Genetic Enhancement'. CGIAR, Science Council Brief 4.

8. The World Economic and Social Survey (2013) Sustainable Development Challenges Department of Economic and Social Affairs of the United Nations Secretariat (UN/DESA), E/2013/50/Rev1 ST/ESA/344.

9. NAIP (2012) Annual report, 2012-13. NAIP, ICAR, Krishi Bhawan, New Delhi, India.

10. NAIP 12, Annual Report 2011-12, National Agricultural Innovative Project, ICAR, New Delhi, India.

11. NAIP (2014) Monitoring and Evaluation Report on National Agricultural Innovation Project. Indian Council of Agricultural Research, New Delhi, India.

12. NAIP (2013) Progress Report of NAIP sub-project on: Strategies for Sustainable Management of Degraded Coastal Land and Water for Enhancing Livelihood Security of Farming Communities (Component 3, GEF funded). Central Soil Salinity Research Institute, Regional Research Station (CSSRI, RRS), Canning Town - West Bengal, India, p. 49.
13. Baker J (2000) Evaluating the Impact of Development Projects on Poverty: A Handbook for Practitioners. Washington, DC, USA, 1(1).

14. Bamberger M (2006) Conducting Quality Impact Evaluations under Budget, Time and Data Constraints. Washington, DC, USA.

15. Caroline Ashley, Karim Hussein (2000) Developing Methodologies for Livelihood Impact Assessment: Experience of the African Wildlife Foundation in East Africa. Overseas Development Institute, Portland House, Stag Place, London, SW1E 5DP, UK.

16. SingerU (2013) Livelihoods and Resource Management Survey on the Mekong between LouangPhabang and Vientiane Cities, Lao PDR. Vientiane, Lao PDR: IUCN. Sustainable Livelihoods Guidance Sheets. FID, UK, pp.122.

17. Bird K (2002) Impact Assessment: An Overview. ODI, London, UK.

18. Duflo E, M Kremer (2003) 'Use of Randomization in the Evaluation of Development Effectiveness'. Paper presented at the World Bank OED Conference on Evaluation and Development Effectiveness, Washington, DC, USA.

19. Elbers C, Gunning J, Hoop K, (2008) 'Assessing Sector-wide Programs with Statistical Impact Evaluation: A Methodological Proposal' World Development 20(10).

20. Fiszbein A (2006) 'Development Impact Evaluation: New Trends and Challenges'. Evidence and Policy 2(3): 385-393(9).

21. Independent Evaluation Group of the World Bank (IEG) (2006) Impact Evaluation: An overview and some issues for discussion.

22. Mandal Subhasis, Sarangi SK, Burman D, Bandyopadhyay BK, Maji B, et al. (2013) Land shaping models for enhancing agricultural productivity in salt affected coastal areas of West Bengal - An economic analysis. Indian Journal of Agricultural Economics 68(3):389-401.

23. Ravallion M (2008) Evaluation in the Practice of Development. Policy Research Working Paper 4547. World Bank, Washington, DC, USA.

24. Baker JL (2000) Evaluating the Impact of Development Projects on Poverty, The World Bank, Washington, DC, USA.

25. Bamberger M (2006) Conducting Quality Impact Evaluations under Budget, Time and Data Constraints, World Bank, Washington, DC, USA.

26. Bamberger M, J Rugh, L Mabry (2006) Real-World Evaluation Working Under Budget, Time, Data, and Political Constraints, Sage Publications, Thousand Oaks, CA, USA.

27. Bamberger M, H White (2007) Using strong evaluation designs in developing Countries: Experience and challenges. Journal of Multidisciplinary Evaluation 4(8): 58-73.

28. Roy AK (2010) Evaluation and Impact Assessment of Technologies and Developmental Activities in Agriculture, Fisheries and Allied Fields. New India Publishing Agency.101 Vikas Surya Plaza, Pitampura, New Delhi, xiv+510p

29. Roy AK (2010) Quantitative methods for Social Science Research. Issues and Tools for social sciences research. (Eds.Kathia et al.), CIFRI, Barrackpore, pp. 391-408.

30. Roy AK (2010) A Study on Statistical Methods for Impact Assessment of Freshwater Aquaculture with Particular Reference to Kolleru Lake, Summer School Proc., WBUF\& AS, Kolkata, India.

31. Roy AK (2010) Methods, Tools and Techniques for Evaluation, Monitoring and Impact Assessment of Development Programme. In: Evaluation and Impact Assessment of Technologies and Developmental Activities in Agriculture, Fisheries and Allied Fields, NIPA, New Delhi, India (eds. A.K Roy), pp. 1-76.

32. Bosc PM (1988b) Evaluation economique de l'expérimentationagronomique: Approchebibliographique. (France: CIRAD?). 
33. Crawford E, M Kamuanga (988) Economic analysis of agronomic trials for the formulation of farmer recommendations. MSU Internationa Development Reprint. East Lansing, MI: Dept. of Agricultural Economics, Michigan State University, USA, p. 6.

34. Herdt R (1987) "Whither farming systems?" In How Systems Work: Proceedings of farming systems research symposium. Fayetteville, Arkansas: Win rock International Institute for Agricultural Development University of Arkansas, USA, p. 3-7.

35. CIMMYT (1988) From agronomic data to farmer recommendations: An economics training manual. Mexico, CIMMYT.

36. Hildebrand PE, F Poey (1985) On-farm agronomic trials in farming systems research and extension. Boulder, CO: Lynne Rienne, 22(2): 200.

37. Norman D W (1987) Farmer groups for technology development: Experiences from Botswana. Paper presented at a workshop on Farmers and Agricultural Research: Complementary Methods, IDS, Sussex, UK.
38. Collinson M P (1982) Farming systems research in Eastern Africa: The experience of CIMMYT and some national agricultural research services 1976-81. MSU International Development. East Lansing, MI: Dept. of Agricultural Economics, Michigan State University, USA, p. 2.

39. Lessley BV, D M Johnson, J C Hanson (1991) Using the Partial Budget to Analyze Farm Change, 1990-1991 Edition, University of Maryland System, p. 7.

40. Devillet R, J Degand, E Dardenne (1981) "The economic benefits of maize cultivation." Guide du maisiculteur et rapport CIPF, pp. 112-127.

41. Dayohimi Rymbai, Sheikh Mohammad Feroze, Ram Singh, Lala P Ray (2017) Application of Partial Budgeting for the Rice Growers of Eastern Himalaya in India. British Journal of Applied Science \& Technology 20(5): 1-8.

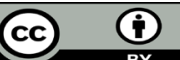

This work is licensed under Creative Commons Attribution 4.0 License

To Submit Your Article Click Here: Submit Article

DOI: 10.32474/OAJESS.2018.01.000120

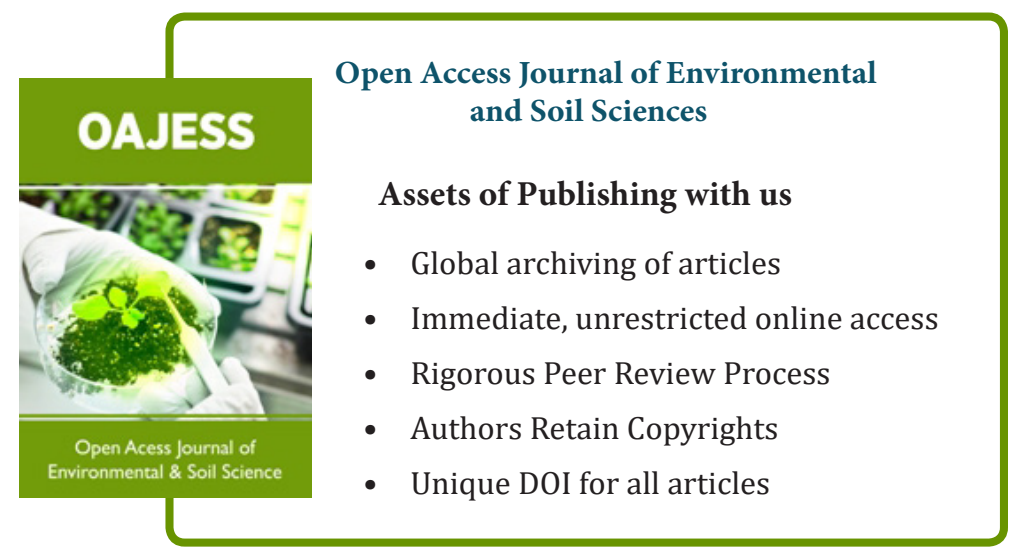

